\title{
Benzyladenine in the Priming Solution Reduces Thermodormancy of Lettuce Seeds
}

\author{
D.J. Cantliffe
}

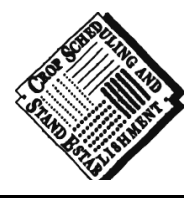

Additional index words. germination, Lactuca sativa, temperature

Summary. When lettuce seeds are imbibed and subjected to high temperature for periods of $72 \mathrm{~h}$ or more, dormancy known as thermodormaney is induced. Priming of three cultivars of lettuce ( Lactuca sativa L.) seeds in $1 \%(\mathrm{w} / \mathrm{v}) \mathrm{K}_{3} \mathrm{P} \mathrm{O}_{4}$ for $20 \mathrm{~h}$ in the dark reduced thermodormaney. Addition of $100 \mathrm{mg}$ 6-benzyladenine (BA)/liter to the priming solution increased germination in petri dishes at $35 \mathrm{C}$ in 'Green Lakes' from 65\% in seeds that were primed without BA, to $92 \%$ when BA was added to the priming solution. In 'South Bay' these percentages were $24 \%$ and $86 \%$, respectively. Seedling emergence was improved in other lots of 'Green Lakes' and 'Montello' using soilless mix.

$\mathrm{T}$ hermodormancy is an important problem in establishing stands of lettuce when seeds are sown under high soil temperatures. It can be circumvented by seedpriming (Cantliffe et al., 1981; Guedes and Cantliffe, 1977, 1980; Guedes et al., 1979). For the procedure to be successful commercially, the components ofpriming must be standardized as much as possible. These components include the type of soak solution (osmoticum) and its osmotic potential, aeration, temperature, light, soak duration, seed redrying procedures, seed storage, and seed quality (Cantliffe, 1983). For lettuce, many of these factors have been standardized, including soaking the seeds in aerated solutions of $1 \%(\mathrm{w} / \mathrm{v}) \mathrm{K}_{3} \mathrm{PO}_{4}$ for $20 \mathrm{~h}$ in the dark (Cantliffe, 1981), followed by redrying the seeds at low temperature and relative humidity to retard radicle growth

Vegetable Crops Department, IFAS, University of Florida, Gainesville, FL 32611.

Florida Agricultural Experiment Station Journal Series no. $R-01437$. 
(Cantliffe et al., 1984). Perkins-Veazie and Cantliffe (1984) found that lettuce thermodormancy can be bypassed successfully by priming high-quality seeds, and that the priming was ineffective with aged or deteriorated seeds.

The upper temperature limit that initiates the onset of thermodormancy varies among cultivars (Thompson et al., 1979). Some cultivars are affected by temperatures slightly above $30 \mathrm{C}$, while others germinate at 33C. Little or no lettuce seed germination occurs above 35C. This difference in temperature sensitivity has led to varied success of priming for overcoming thermodormancy.

Cytokinins reduced thermodormancy in lettuce, especially when seeds were germinated directly in cytokinin solutions (Sharples, 1973). When seeds were soaked in cytokinin and subsequently sown apart from the hormone, the treatment was generally ineffective (Smith et al, 1968). In our work, a cytokinin (BA) was added to the priming solution in an attempt to ensure high germination percentages oflettuce after the seeds were dried and imbibed at $35 \mathrm{C}$, regardless of cultivar or seed source.

Lettuce seeds were primed under similar conditions throughout all experiments. BA (Abbott Laboratories, North Chicago, Ill.) was added as a treatment to the priming solution. Seeds were primed at $15 \mathrm{C}$ in aerated $1 \%(\mathrm{w} / \mathrm{v}) \mathrm{K}_{3} \mathrm{PO}_{4}$ in the dark for $20 \mathrm{~h}$. The seeds were placed in 200-mm test tubes with $20 \mathrm{ml}$ of soak solution per gram of seeds. After priming, the seeds were washed with $100 \mathrm{ml}$ of distilled water and surface moisture was removed by 2 to $3 \mathrm{~min}$ of suction. The seeds were dried immediately and stored at $5 \mathrm{C}, 45 \% \mathrm{RH}$.

Germination tests were conducted in incubators in the dark by placing 25 seeds on Whatman No. 3 filter paper in a 9-cm-diameter petri dish and adding $5 \mathrm{ml}$ of distilled water followed by covering. Each treatment was replicated four times and most experiments were repeated at least twice. Germination, defined as visible radicle protrusion through the seedcoat and pericarp, was counted daily for 5 days. Average number of days to germination (ADG) was calculated according to the following formula:

$A D G=\left(A_{1} T_{1}+A_{2} T_{2}+\ldots A n T n\right) /$ $\left(A_{1}+A_{2}+\ldots A n\right)$ where: $\mathrm{A}=$ number of seeds germinating per day, $\mathrm{T}=$ time corresponding to $\mathrm{A}$ in days, and $\mathrm{n}=$ number of days to final count.

In the first experiment, 'Green Lakes' and 'South Bay' lettuce seeds were primed without BA, dried, then germinated at $10,15,25,30$, or $35 \mathrm{C}$. In the second experiment with the same cultivars, BA was added to the priming solution in concentrations ranging from 0 to $500 \mathrm{mg}$. In the third experiment, 'Green Lakes' (a different seed lot from the above) and 'Montello' lettuce seeds were primed with or without $100 \mathrm{mg} \mathrm{BA} / \mathrm{liter}$, dried, then germinated in incubators at 15,25 , or $35 \mathrm{C}$ or in a 1 peat: 1 vermiculite (v/ v) mix in growth chambers maintained at constant 15 or $35 \mathrm{C}$.

Germination of 'Green Lakes' and 'South Bay' was high (98\%), regardless of treatment, at $10,15,25$, and $30 \mathrm{C}$ (data not shown). At 35C, only primed seeds germinated, however, values were low-52\% for 'Green Lakes' and 36\% for 'South Bay'. ADG at 10 or $15 \mathrm{C}$ was improved for both cultivars by priming (Table 1). At 25 and 30C, ADG was similar for control and primed seeds.

With $25 \mathrm{mg}$ BA/liter priming solution, germination of 'Green Lakes' at 35C increased from $65 \%$ to $85 \%$, but higher BA concentrations did not increase germination further (Fig. 1). Germination of 'South Bay' seeds at $35 \mathrm{C}$ was not increased by BA addition until $\geq 100 \mathrm{mg}$ BA/liter was added to the priming solution. Subsequent additions of 150,250 , and $500 \mathrm{mg}$ BA/liter further increased germination of this cultivar. Abnormal germination, manifested as thickened hypocotyls, was observed in seedlings primed at 250 or $500 \mathrm{mg}$ BA/liter. Morphological abnormalities were not observed in seedlings primed in 100 mg BA/liter; thus, this concentration was selected for the third experiment. In a third experiment with different seed lots, percentage germination at 15 and $25 \mathrm{C}$ was unaffected by seed priming, with or without $\mathrm{BA}$ in the osmoticum (Table 2). At 35C, only primed 'Green Lakes' seed germinated, and the addition of BA to the priming solution increased germination significantly. Results with 'Montello' were similar. At $15 \mathrm{C}$, seed priming decreased $\mathrm{ADG}$, but at 25 or $35 \mathrm{C}$, ADG was the same whether or not the seeds were primed.

When primed or nontreated seeds were sown in soilless mix in the growth chamber, emergence at $15 \mathrm{C}$ was unaffected bypriming (Table 3). At 35C, percentage emergence of primed seed was low in both cultivars unless BA was used. ADS; at $15 \mathrm{C}$ was not affected by seed priming.

Seed priming effectively overcomes thermodormancy in lettuce both in the laboratory and the field (Cantliffe, 1981). In the past, the actual germination percentage of primed seeds achieved at $35 \mathrm{C}$ has varied, ranging from $50 \%$ to $80 \%$. With the addition of BA to the priming solution, germination at $35 \mathrm{C}$ was generally $>90 \%$, a germination percentage similar to that achieved at an ideal germination temperature (25C). Previous reports using cytokinin to improve germination of lettuce at high temperatures relied on either leaving the growth regulator in contact with the seed during germination (Sharples, 1973) or pregerminating the seed directly in cytokinin solutions at low temperature and then transferring the seed to the high temperature (Smith et al., 1968). The results from the former procedure were generally more favorable, while those from the latter usually led to $<50 \%$ germination.

Germination at $35 \mathrm{C}$ in a soilless

Table 1. Bffects of temperature and seed priming on average days to germination (ADG) by two lettuce cultivars.

\begin{tabular}{llccccc}
\hline & \multicolumn{7}{c}{ Seed } & \multicolumn{7}{c}{ Temperature $\left({ }^{\circ} \mathrm{C}\right)$} \\
\cline { 3 - 7 } Cultivar & treatment & 10 & 15 & 25 & 30 & 35 \\
\hline \multirow{3}{*}{ Green Lakes } & & \multicolumn{7}{c}{ ADG (days) } \\
& Control & 3.1 & 2.0 & 1.0 & 1.6 & $\ldots$ \\
& Primed & 2.4 & 1.1 & 1.0 & 1.4 & 1.0 \\
South Bay & & $*$ & $*$ & NS & NS & \\
& Control & 3.1 & 2.0 & 1.1 & 1.8 & $\ldots$ \\
& Primed & 2.2 & 1.1 & 1.1 & 1.5 & 1.1 \\
& & $*$ & $*$ & NS & NS &
\end{tabular}

;NSSed treatments within a temperature and cultipar significantly different or not significant at the $5 \%$ level ( $F$ test), respectively. 


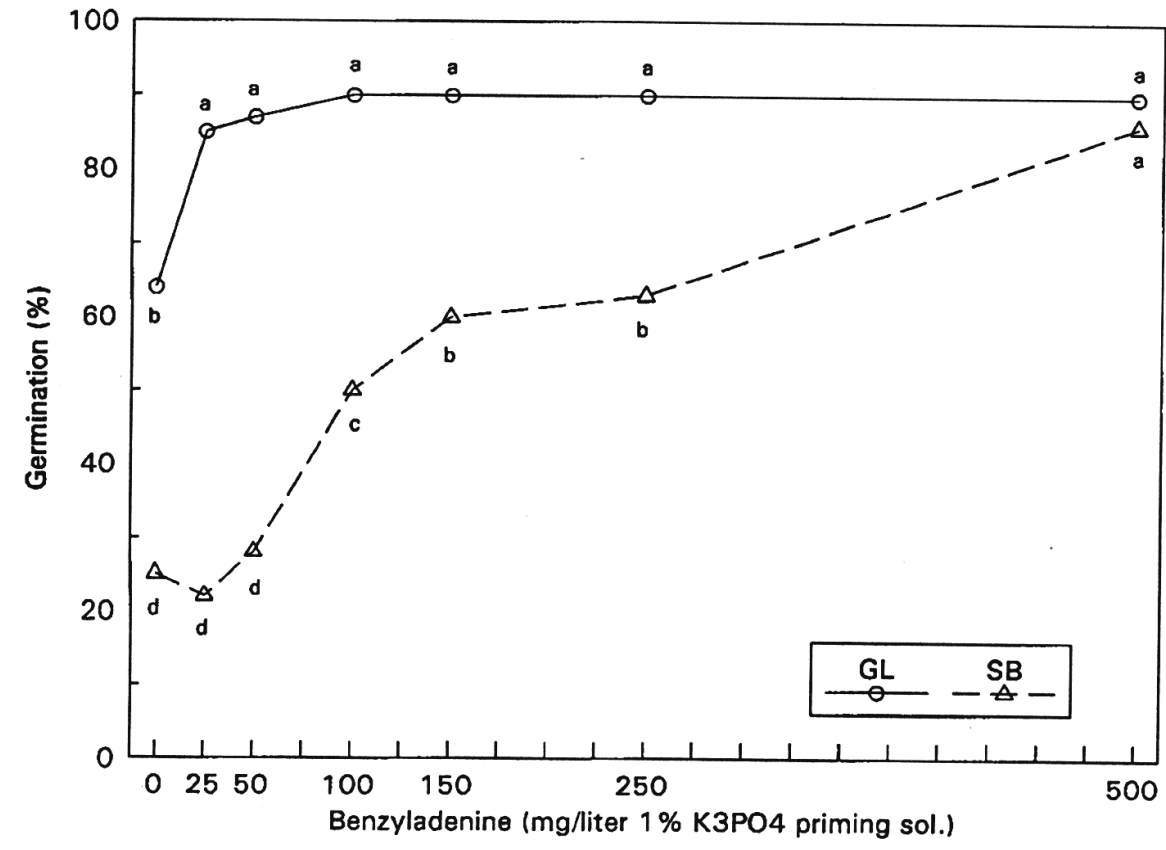

Fig. 1. Germination at 35C of 'Green Lakes' (GL) and 'Soutb Bay' (SB) lettuce seeds in petri dishes after priming with 0 to $500 \mathrm{mg} B A$ liter of $1 \% K_{3} P O_{4}$. Mean separation within cultipars is by Duncan's multiple range test at the $5 \%$ level.

Table 2. Effects of priming witb BA on germination and average days to germination of two lettuce cultivars at different temperatures.

\begin{tabular}{|c|c|c|c|c|c|c|c|}
\hline \multirow{2}{*}{ Cultivar } & \multirow{2}{*}{$\begin{array}{c}\text { Seed } \\
\text { treatment }\end{array}$} & \multicolumn{6}{|c|}{ Temperature $\left({ }^{\circ} \mathrm{C}\right)$} \\
\hline & & 15 & 25 & 35 & 15 & 25 & 35 \\
\hline & & \multicolumn{3}{|c|}{ Germination (\%) } & \multicolumn{3}{|c|}{$A D G(\text { days })^{y}$} \\
\hline \multirow[t]{3}{*}{ Green Lakes } & Control & 97 a & 97 a & $0 \mathrm{a}$ & $2.0 \mathrm{a}$ & 1.0 & $-\cdots$ \\
\hline & Primed & 94 a & $100 \mathrm{a}$ & $76 \mathrm{~b}$ & $1.3 \mathrm{~b}$ & $1.0 \mathrm{a}$ & $1.0 \mathrm{a}$ \\
\hline & Primed + BA & 94 a & 99 a & $90 \mathrm{c}$ & $1.0 \mathrm{c}$ & $1.0 \mathrm{a}$ & $1.0 \mathrm{a}$ \\
\hline \multirow[t]{3}{*}{ Montello } & Control & 99 a & $100 \mathrm{a}$ & 16 a & $1.5 \mathrm{a}$ & $1.0 \mathrm{a}$ & $1.0 \mathrm{a}$ \\
\hline & Primed & $100 \mathrm{a}$ & 96 a & $60 \mathrm{~b}$ & $1.3 \mathrm{~b}$ & $1.0 \mathrm{a}$ & $1.0 \mathrm{a}$ \\
\hline & Primed + BA & 99 a & 99 a & $91 \mathrm{c}$ & $1.0 \mathrm{c}$ & $1.0 \mathrm{a}$ & $1.0 \mathrm{a}$ \\
\hline
\end{tabular}

srimed $=1 \% \mathrm{~K}_{3} \mathrm{PO}_{4}\left(15 \mathrm{C}, 20 \mathrm{~h}\right.$, dark). Primed $+B \mathrm{~A}=100 \mathrm{mg} \mathrm{BA} /$ liter, $1 \% \mathrm{~K}_{3} \mathrm{PO}_{4}(15 \mathrm{C}, 20 \mathrm{~h}$, dark). 'Means within a cultivar and temperature separated by Duncan's multiple range test, $5 \%$ level.

Table 3. Effects of priming with $B A$ on emergence percentage and average days to emergence $(A D E)$ of two lettuce cultivars at different temperatures in soilless mix in growth cbambers.

\begin{tabular}{|c|c|c|c|c|c|}
\hline Cultivar & $\begin{array}{c}\text { Seed } \\
\text { treatment }\end{array}$ & \multicolumn{4}{|c|}{ Temperature $\left({ }^{\circ} \mathrm{C}\right)$} \\
\hline \multirow{4}{*}{ Green Lakes } & & \multicolumn{2}{|c|}{ Emergence (\%) } & \multicolumn{2}{|c|}{$A D E$ (days) } \\
\hline & Control & 90 a & $0 a^{z}$ & $5.6 \mathrm{a}$ & ... \\
\hline & Primed & $83 a$ & $17 \mathrm{~b}$ & $6.9 \mathrm{a}$ & $4.0 \mathrm{a}$ \\
\hline & Primed + BA & $96 a$ & $68 c$ & $5.6 \mathrm{a}$ & $3.4 \mathrm{a}$ \\
\hline Montello & Control & $96 a$ & $4 \mathrm{a}$ & $6.5 \mathrm{a}$ & $4.3 \mathrm{a}$ \\
\hline & Primed & 94 a & $34 \mathrm{~b}$ & $5.9 \mathrm{a}$ & $3.7 \mathrm{a}$ \\
\hline & Primed + BA & 95 a & $65 \mathrm{c}$ & $5.6 \mathrm{a}$ & $3.9 \mathrm{a}$ \\
\hline
\end{tabular}

Means significantly different at the 5\% level within temperatures, Duncan's multiple range test.

mix was improved 2-fold for 'Montello' and 4-fold for 'Green Lakes' when BA was added to the priming solution. Heydecker and Joshua (1977) observed reduced germination at $29 \mathrm{C}$ when kinetin-soaked lettuce seeds were germinated in a potting mix instead of be most effective when high-quality seeds are soaked at $15 \mathrm{C}$ in aerated osmotic solutions (salt or polyethylene glycol) at concentrations that prohibit radicle growth. The addition of cytokinin improves the overall effectiveness of the priming treatment and tends to reduce treatment variances due to seed source or cultivar.

\section{Literature Cited}

Cantliffe, D.J 1981. Seed priming of lettuce for early and uniform emergence under conditions of environmental stress. Acta Hon. 122:29-38.

Cantliffe, D.J. 1983. Starting vegetable cropswith primed seed. Amer. Veg. Grower 31:42-43.

Cantliffe, D.J., J.M. Fischer, and T.A. Nell. 1984. Mechanism of seed priming in circumventing themodormancy in lettuce. Plant Physiol. 75:290-294.

Cantliffe, D.J, K.D. Shuler, and A.C. Guedes. 1981. Overcoming seed thermodormancy in a heat-sensitive romaine lettuce by seed priming. HortScience 16:196198.

Guedes, A.C. and D.J Cantliffe. 1977. Effect of presowing seed treatments on germination of lettuce seed at high temperature. Proc. Fla. State Hort. Soc. 90:418-420.

Guedes, A.C. and D.J. Cantliffe. 1980. Germination of lettuce seeds at high temperature after seed priming. J. Amer. Soc. Hort. Sci. 105:777-781.

Guedes, A.C., D.J. Cantliffe, K.D. Shuler, and E. Munter. 1979. Overcoming thermodormancy in lettuce by seed priming. Proc. Fla. State Hort. Soc. 92:130133.

Heydecker, W, and R. Joshua. 1977. Alleviation of the thernmdormancy of lettuce ( Lactuca sativa L.) seeds. J. Hort. Sci. 52:87-98.

Perkins-Veazie, P. and D.J. Cantliffe. 1984. Need for high quality seed for priming to effectively overcome thermodormancy in lettuce. J. Amer. Soc. Hort. Sci. 109:368372.

Sharples, G. C. 1973. Stimulation of lettuce seed germination at high temperatures by ethephon and kinetin. J. Amer. Soc. Hort. Sci. 98:209-212.

Smith, O.E., W. Yen, and J.M. Lyons. 1968. The effects of kinetin in overcoming high temperature dormancy of lettuce seed. Proc. Amer. Soc. Hort. Sci. 93:444-453.

Thompson, P.A., S.A. Cox, and R.H. Sanderson. 1979. Characterization of the germination responses to temperature of lettuce ( Lactuca sativa L.) achenes. Ann. Bot. 43:319-334. 